\title{
PROFESSIONAL POLICE OFFICERS BEHAVIOUR IN CRITICAL SITUATIONS
}

\author{
Egidijus Nedzinskas \\ Lithuania Business University of Applied Sciences, Lithuania \\ Rūta Nedzinskienè \\ Lithuania Business University of Applied Sciences, Lithuania \\ Renata Šliažienè \\ Lithuania Business University of Applied Sciences, Lithuania
}

\begin{abstract}
Fast-moving processes in today's society make the importance of prompt, responsible and professional decision-making by police officers. In everyday situations that do not require important and urgent decisions, the police officer can act appropriately and avoid hasty, inadequate decisions. However, the police officer must always be prepared to face an emergency situation, to evaluate it correctly and to use the powers granted to resolve it. The only one wrong decision can have irreversible consequences for the police officer or the public. This paper aims to investigate the behaviour of professional police officers in everyday and critical situations. The research was based on scientific literature analysis and statistical data analysis. One of Lithuanian universities where future police officers are educated has been chosen for the study. A written survey for students - future police officers was performed. The study has shown that police officers, performing their daily duties without the need to take especially important decisions or making critical decisions on which depend the fate of the human, feel the legal liability and social responsibility. In critical situations requiring officers' self-decision, these decisions are affected by the officers' sense of responsibility to people, his/her obligation to comply with the law and fear of punishment if the law is violated.
\end{abstract}

Keywords: Critical Situations, Liability, Police Officers, Responsibility.

\section{Introduction}

The police are the one of the main institutions ensuring public security and public order in the country. Quality of the being implemented decisions ensuring public security and public order as well as quality of public life in the country depend upon qualified and professional police officers. The aim of the police is to ensure the professional, transparent and impartial implementation of state tasks in the country. Almost every day a police officer is involved in inadequate situations and has to make decisions. 
The present time dictates new situations and, without a properly designed legal framework, a police officer may be unable to escape responsibility, whether he/she acted and performed his/her duty in a situation of increased danger, or feeling the fear and not weighing is the decision appropriate, failed to perform his/her duty properly or did not perform his/her duty at all. Just one injudicious decision or improper performance of the duty can have irreversible consequences for a police officer or the public. There is a fear or lack of knowledge of the law, where a police officer may delay in performing, improperly performing or not performing his/her direct duties at all, but the police officer may be liable for such actions in accordance with the law. Therefore, where are those levers for making the right decision when, in "noanalog" situations, a police officer has to make an important, considered, expeditious and right decision?

Scientists emphasise different points when it comes to the work of police officers in critical situations. Uspanov, Turabayevaa and Ermolovichb (2016), Šalkauskaite, Valickas, Grikšienė and Rukšènas (2015) analyse the importance of psychological competence in the work of a police officer. Sommera, Njå and Lussand (2017) examine how police officers with command responsibilities learn to carry out emergency response work and manage emergencies. Other scientists focused on the police officers resolving crisis incidents involving dangerous individuals (Hyde, 2016) or mentally ill population (Horne, 2018). Forde, Lægreid, Rubecksen and Rykkja (2018) highlight one of the most serious emerging risks with which policemen are confronted in their work, a risk which often falls within the usual term of work-related accident, namely the results of the actions of a certain category of citizens directed against police officers involving striking or other violence, bodily injury, injuries causing death or even murder.

This article is specifically focused on the motivations of police officers in critical situations and the scientific issue of the article is formulated with the question: What determines the behaviour of a professional police officer in critical situations?

The aim of the article is to investigate the behaviour of professional police officers in everyday and critical situations.

Tasks of the article: 1) to highlight the issues of the behaviour of police officers in critical situations; 2) to analyse empirically the behaviour of professional police officers in everyday and critical situations.

Methods used in the article: analysis of scientific literature, statistical data analysis. 


\section{Theoretical framework}

The police officers often find themselves in critical situations doing complex and versatile public order protection work, taking care of road safety and fighting against the crime. In every situation, a police officer must act with skilfully, precisely and with determination. It is often on his/her depends the future direction of the situation development, sometimes even the health or life of the people.

From the point of view of the police, a crisis situation may be compared to a special situation, which is characterized by abruptness and a considerable threat to human life, health or property of significant size, as well as a facilities, which are important for state security or defence, such that controlling it requires additional and extraordinary police forces and measures (Uchroński, 2016).

The particularity of the work of police officers is related to the fact that they have to work and make decisions in emergency circumstances more often than representatives of other professions (Šalkauskaite et al., 2015). Alexander and Walker (2000) point out that a police officer may, over the course of his/her career, be repeatedly involved in situations which endanger his/her safety or even his/her life. Being involved in these situations a person can feel insecure in his/her daily live. Norkus, Dirvelyte and Karpenko (2014) notes that police officers' stress is caused by the fact that they have a personal security problem by themselves.

The studies carried out by Brought and Williams (2007) revealed that the work of police officers poses greater stress due to safety of other people as well. This is likely to be due to the wide variety of situations in which police officers work when it comes to ensuring the safety of another person, which makes it more difficult to get used to the stress. The authors Žukauskas, Burba, Rukšènas, Grigaliūnienè and Mitchell (2009), Ruibyte (2011) note that police officers are exposed to a variety of physiological, psychological and behavioural stressors in their work. After carrying out research in their works, Thoits (1999), Acquadro Maran, Varetto, Zedda and Franscini (2014) point out that police officers can be exposed to a variety of stress situations and become socially vulnerable, making it difficult for them to make the right decisions. Šalkauskaite et al. (2015) state that decision-making of police officers in emergency circumstances leads to higher stress levels of the officers and universal competencies help to manage the situation.

A police officer, unlike other civil servants, must be able to fulfil both the roles that a police officer has and comprehend in unforeseen circumstances and situations. In the face of the processes of European integration, a police officer must be able to solve non-standard issues that arise, and also have a sense of 
social responsibility not only for individual but also for group work (Prakapa \& Čepaite, 2011). Thus, a police officer must be guided not only by law, but also by his/her own human characteristics. Therefore, it should be emphasised that the specific nature of the activities of police officers leads to their own particular concept of responsibility. Police officers, in comparison with civil servants of other institutions, have additional social responsibilities but they are not exempt from their own liability by the laws. The peculiarity of policing is that they have both social responsibility and legal liability.

According to Nedzinskienè and Nedzinskas (2018), social responsibility means caring for another person (s), helping him/her, willingness to be fair in his/her relationship with other people, and being demanding, that the other one(s) would be righteous, conditioned by the personally recognised interpersonal values. Legal liability, as Nedzinskas and Nedzinskienè (2017) point out, is a legal obligation to be responsible for one's actions and acts and to evaluate them; this obligation is conditioned by liability before the law; often the legal liability of a person is reminded of the fear that in case of offend the one will be punished according to the relevant law.

However, Misiūnas (2008) points out that officers fearing possible liability often do not use special measures and choose the role of victim rather than government representative. Such fear arises from the sufficiently strict liability, the established case law and the low qualification of police officers. According to Juraševič (2001), among the motives, which are followed by police officers in their service is the "law requires", so they are afraid of liability due to violations of lawfulness. Misiūnas (2010) assumes that the fear of legal liability limits the actions of officers and, thus, affects the quality of police officers' functions. According to Misiūnas (2010), every time officers balance on the dangerous threshold: passive reaction to a violation of law - possibility to be accused of failure to perform duties; over-emotional reaction and irresponsible exercise of rights - the possibility of being accused of an excess of authority. Every mistake is painful for a police officer and for the entire police system.

In conclusion it can be stated that a police officer must make an urgent but socially and legally responsible decision in a critical situation. A police officer has to act quickly, skilfully, adequately and without fear in the most demanding situations.

\section{Methodology}

The original questionnaire as the research instrument was used for the investigation of police officers behaviour in critical situations. A written survey was performed using this questionnaire. Recipients were asked to fill their answers to the following questions: 
- What would a police officer feel like performing his/her everyday job which does not require crucial decisions?

- What would a police officer feel if he had to make crucial decisions that would affect a person's fate?

- $\quad$ Is the decision made by a police officer in critical situations requiring self-determination influenced by following: 1) a sense of responsibility towards a person; 2) the duty to comply with the law; 3) fear of being punished if the law is breached?

One of Lithuanian universities where study program "Law and Police Activities" is performed was chosen for the investigation. 102 students - future police officers participated in the survey in 2011 and 109 students - in 2015.

Statistical data analysis using IBM SPSS 23.0 software was performed for the processing results of the written survey.

\section{Results}

The performed analysis has indicated the behaviour of police officers in everyday and critical situations.

A police officer performing his/her everyday duties which do not require crucial decisions. Students - future police officers were asked to imagine themselves as police officers and they were asked what would they feel like performing everyday duties which did not require making crucial decisions? The results are presented in Fig. 1.

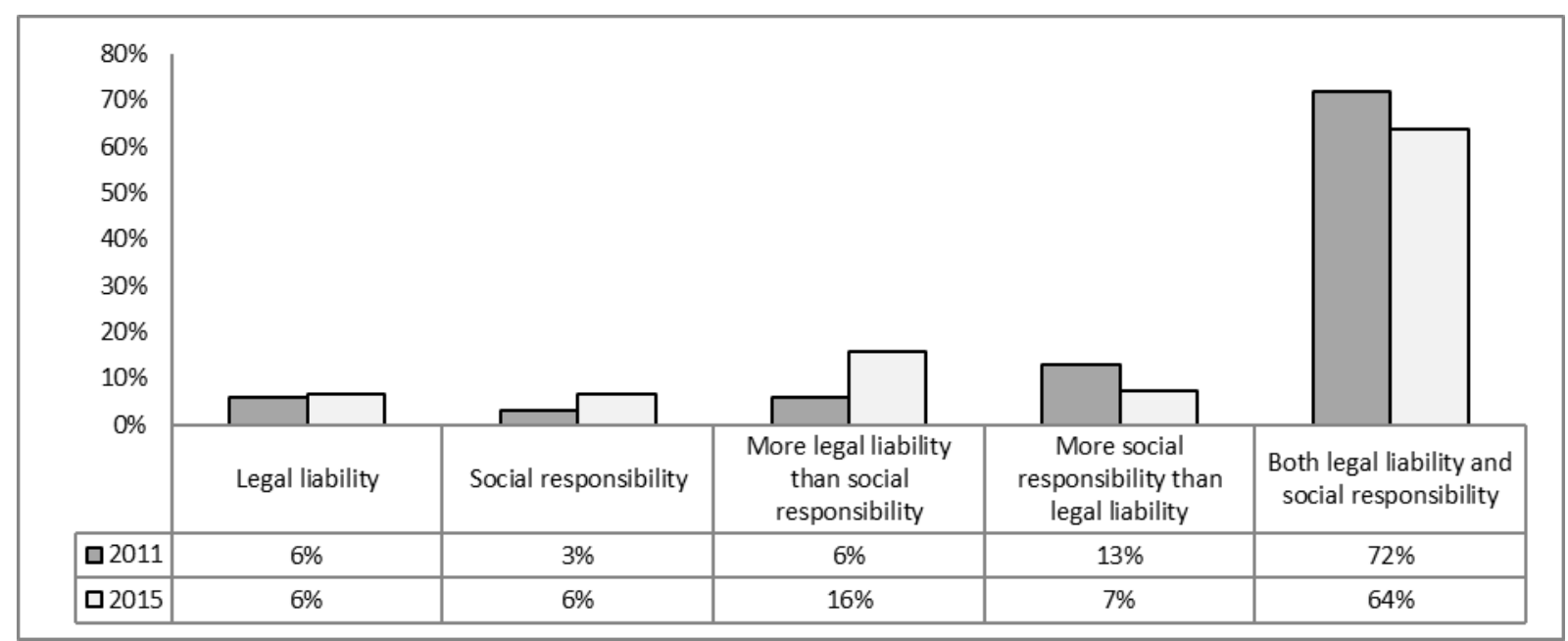

Figure 1 Distribution of respondents' opinions on legal liability and social responsibility when performing everyday duties which did not require making crucial decisions, in 2011 and 2015 
72\% in 2011 and 64\% in 2015 of all respondents, who participated in the survey, indicated that they would feel legal liability and social responsibility when performing their everyday duties which do not require crucial decisions. Therefore, it could be stated that future police officers would follow both the statutory norms and their own intrinsic value system.

It can be either stated that over time the views have changed and that future professionals become more and more legally responsible. Such their choice may have been determined by current issues in Lithuania, where legal liability becomes more important than social responsibility, as every decision made by a police officer is subject to official inspection and the office, who offended the law, is subject to disciplinary / official, administrative, criminal or substantive / civil liability. Police officers without feeling social responsibility take risks and may be condemned by the society or the media.

A police officer who would to make crucial decisions which would affect a person's fate. The students were also asked to imagine themselves as police officers and were asked what would they feel like making crucial decisions which would affect a person's fate? The results are presented in Fig. 2.

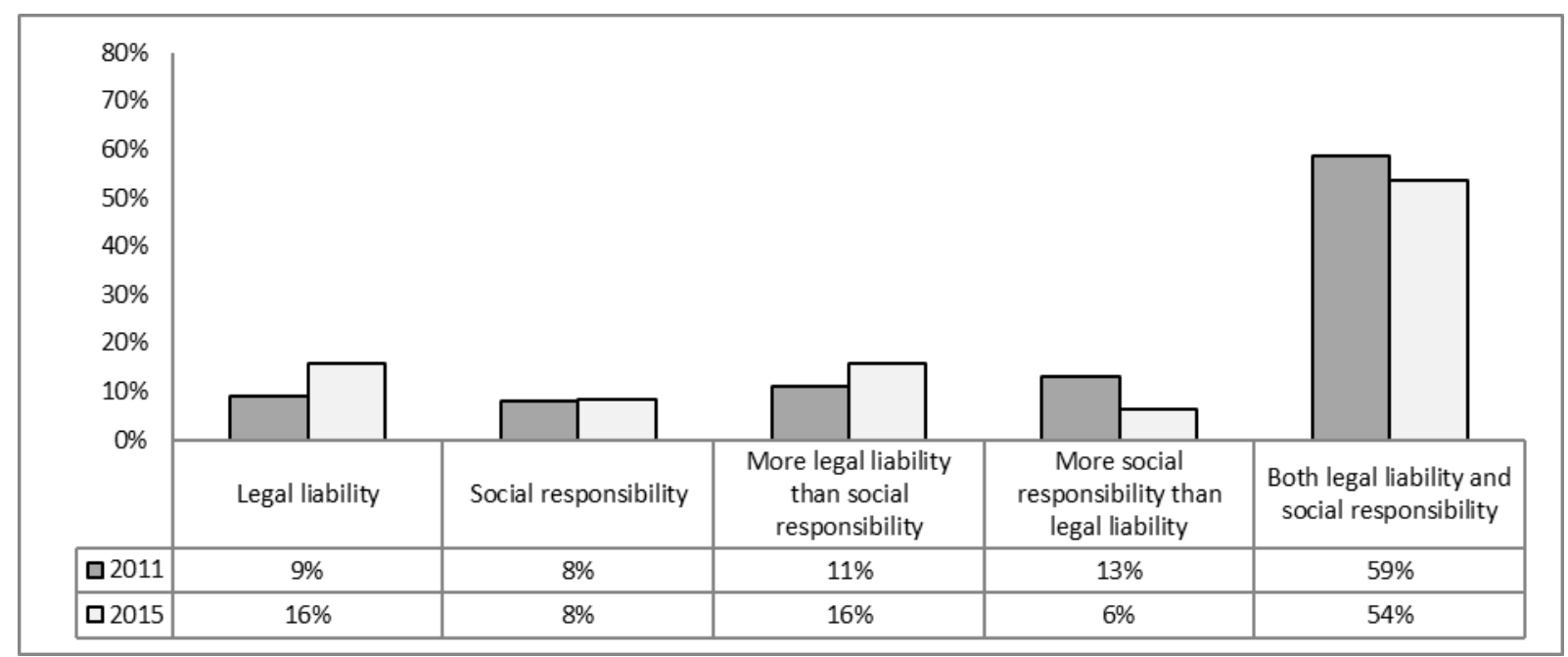

Figure 2 Distribution of respondents' responses to legal liability and social responsibility whether they have to make crucial decisions which would affect a person's fate, in 2011 and 2015

59\% in 2011 and 54\% in 2015 of all respondents, who participated in the survey indicated that if they had to make crucial decisions which would affect a person's fate that they would feel legal liability and social responsibility. The same tendency is observed as in the case of everyday duties; i.e. there is a growing awareness of legal liability versus social responsibility.

The aim was also to determine whether there is a relationship between the feelings of respondents when performing their everyday duties and their feelings 
when making crucial decisions which would affect a person's fate. To measure the relation between the respondents' answers to the questions about their feelings, there was calculated the Kramer's V ( V = 0.078; $\mathrm{p}=0.642)$ coefficient. There was determined that respondents' feelings performing their everyday duties and feelings when making crucial decisions are independent and there was no statistically significant relation between the choice of the options of answers.

A decision made by a police officer in critical situations. Opinion of the respondents, who participated in the survey, on that in critical situations requiring self-determination their decision-making is influenced by a sense of responsibility towards a person, had no statistically significant difference $(\chi 2=3.900 ; p=0.142)$ in 2011 and in 2015. In $2011-52 \%$, and in $2015-65 \%$ of all interviewed students - respondents indicated that in critical situations requiring self-determination their decision-making is influenced by a sense of responsibility towards a person.

Students, future police officers, were also asked a two-part question. The first part of the question asked students - respondents whether they can say that in critical situations requiring self-determination their decision-making is influenced by the duty to comply with the law. In another part of the question, future professionals were asked about their fear of breaking the law: can you say that in critical situations that require self-determination, your decision-making is influenced by the fear of being punished if the law is violated?

Opinion of the respondents, who participated in the survey, on that in critical situations that require self-determination, their decision-making is influenced by the duty to comply with the law had no statistically significant difference $\left(\chi^{2}=3.708 ; p=0.447\right)$ in 2011 and 2015. For the most part, in $2011-61 \%$, and in $2015-72 \%$ of the respondents, who participated in the survey, indicated that in critical situations requiring self-determination their decision-making is influenced by the duty to comply with the law.

Meanwhile, the opinion of the respondents that in critical situations that require self-determination, their decision-making is influenced by the fear of being punished if the law is violated in 2011 and 2015 were statistically significantly different $\left(\chi^{2}=18.345 ; p=0.001\right)$. In 2011 a half, i.e. $50 \%$ and in 2015 already $72 \%$ of all respondents, who participated in the survey said that their decision-making in critical situations requiring self-determination is influenced by the fear of being punished if the law is violated (see Figure 3). 


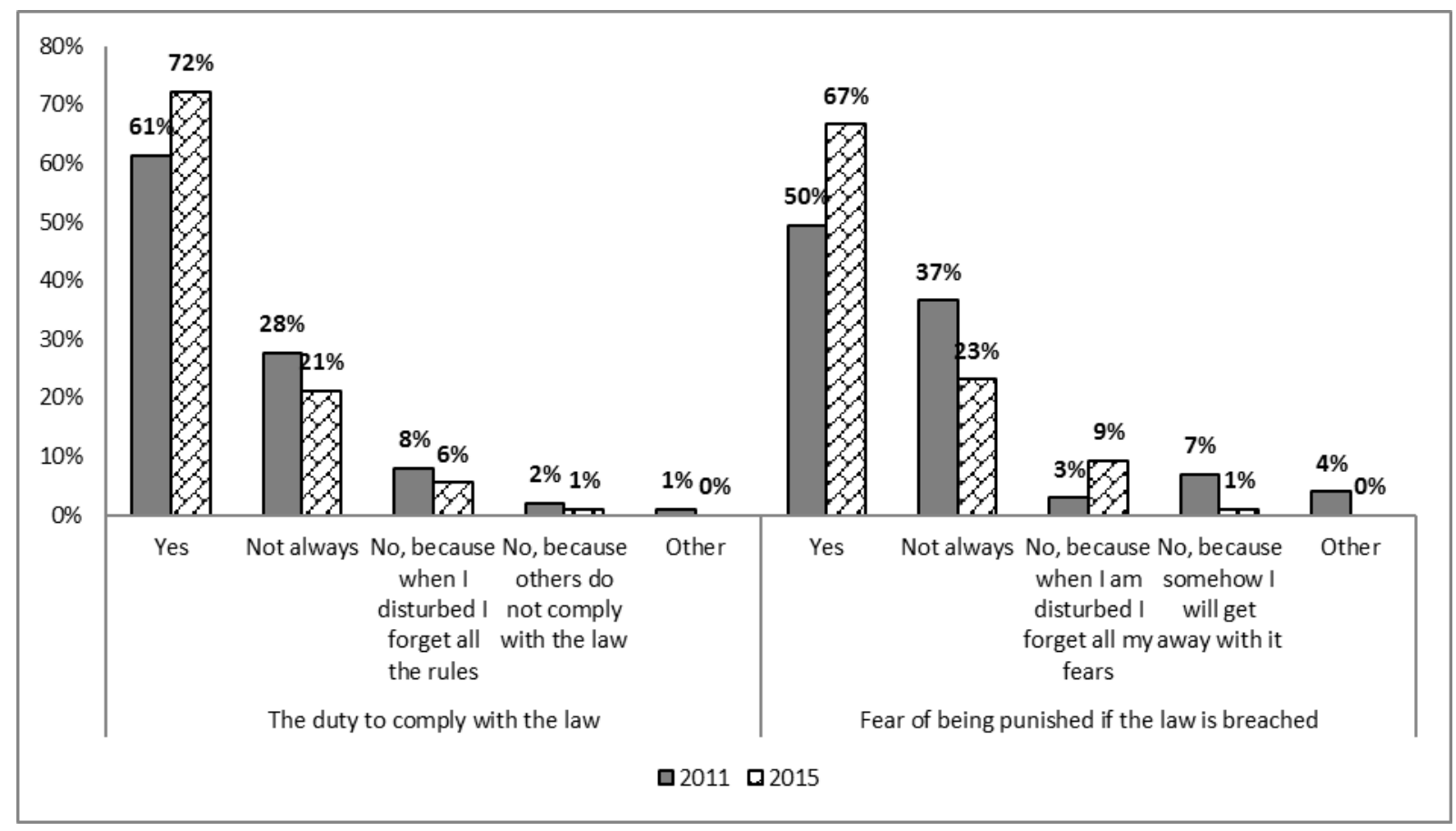

Figure 3 Distribution of the answers of the respondents about their duty to comply with the law in critical situations that require self-determination and the fear of being punished if the law is violated, in 2011 and 2015

There was also identified a statistically significant relation between choice of answers of the respondents on whether their decision-making in critical situations is influenced by (1) the duty to comply with the law and (2) the fear of being punished if the law is violated. For this purpose, the Kramer's $\mathrm{V}$ coefficient $(\mathrm{V}=0.273 ; \mathrm{p}<0.000)$ was calculated. There was determined that respondents who states that their decision-making in critical situations is influenced by the duty to comply with the law have also been found to be affected by the fear of being punished if the law is violated.

\section{Conclusions}

Police officers have to work and make decisions in critical situations more often than representatives of other professions. A police officer is often responsible of the future direction of the situation development, sometimes even the health or life of the people. Thus police officers feel greater stress while ensuring safety of other people. A police officer, unlike other civil servants, must be able to fulfil the roles that a police officer has and comprehend in unforeseen circumstances and situations. Thus, a police officer must be guided not only by law, but also by his/her own human characteristics. The peculiarity of policing is that they have both social responsibility and legal liability. 
The investigation has shown that feelings of the respondents performing their everyday duties and feelings making crucial decisions are independent. There was determined that most of the respondents feel both legal liability and social responsibility performing their everyday duties which do not require crucial decisions. Therefore, it could be stated that future police officers would follow both the statutory norms and their own intrinsic value system. In everyday situations the police officer is left free to act appropriately in order to avoid inadequate decisions.

The majority of the respondents who participated in the survey indicated that in critical situations requiring self-determination, their decision-making is influenced by their sense of responsibility to the person and the duty to comply with the law. There was also determined that respondents who states that their decision-making in critical situations is influenced by the duty to comply with the law have also been found to be affected by the fear of being punished if the law is violated. It is noteworthy that the fear of being punished if the law is violated is increasing when comparing 2015 with 2011. Avoiding their duties police officers do not always respond to violations of law, and this leads to deterioration in efficiency police activity and partnerships between the police and society. Institution of officer liability not only discipline or oblige officers to perform police functions properly or use coercive measures in a responsible manner, but it also creates an excessive fear of liability.

\section{References}

Acquadro Maran, D., Varetto, A., Zedda, M., \& Franscini, M. (2014). Stress among Italian male and female patrol police officers: a quali-quantitative survey. Policing: An International Journal, 37(4), 875-890.

Alexander, D.A., \& Walker, L.G. (2000). Is my stress greater than yours? A comparison of policemen and firemen. International Journal of Police Science and Management, 2, 303-312.

Brought, P., \& Williams, J. (2007). Managing occupational stress in a high-risk industry: Measuring the job demands of correctional officers. Criminal Justice and Behavior, 34, 555-567.

Førde, J.S., Lægreid, P., Rubecksen, K., \& Rykkja, L.H. (2019). Organizing for Societal Security and Crisis Management in Germany, The Netherlands, Norway, Sweden and the UK. In Lagreid P., Rykkja L. (Eds.), Societal Security and Crisis Management. New Security Challenges. Palgrave Macmillan, Cham.

Horne, C.A. (2018). Crisis Intervention Team (CIT) Training: Differences Between Police Officers' Response and Resolution to Situations. ProQuest Dissertations: Publishing Capella University.

Hyde, R. (2016). The role of civil liability in ensuring police responsibility for failures to act after Michael and DSD. European Journal of Current Legal Issues, 22(1).

Juraševič, N.M. (2001). Teisinės sąmonès vaidmuo kuriant teisinę valstybę. Jurisprudencija, 19(11), 19-22. 
Misiūnas, E. (2008). Policijos pareigūno teisinio statuso elementų pusiausvyros problema. Jurisprudencija, 4(106), 100-107.

Misiūnas, E. (2010). Policijos pareigūnu teisinis statusas. Daktaro disertacija. Mykolo Romerio univeritetas. Vilnius: MRU.

Nedzinskas, E., \& Nedzinskiene, R. (2017). Medical professionals as the social sensitive group: analysis of responsibility. Medical Physics in the Baltic States 2017 Proceedings of the 13th International Conference on Medical Physics, 13, 81-84.

Nedzinskienè, R., \& Nedzinskas, E. (2018). Evaluation of Legal and Social Responsibility: the Case of Future Police Officers. Society. Integration. Education. International Scientific Conference, 5, 185-195.

Norkus, A., Dirvelyte, S., \& Karpenko, E. (2014). Policijos pareigūnų darbe patiriamas stresas ir jo sąsajos su profesiniu nuovargiu: Šiaulių ir Kauno apskričių vyriausiuju policijos komisariatų atvejai. Visuomenès saugumas ir viešoji tvarka, 11, 145-163.

Prakapa, R., \& Čepaitė, V. (2011). Kritinio mąstymo ugdymo galimybès teisinio ugdymo pamokose. Socialinis darbas, 10(2), 181-192.

Ruibytė, L. (2011). Asmenybės ypatumų ryšys su streso pasekmių vertinimu ir streso ịveikimo pobūdžiu statutinèje organizacijoje, Visuomenès saugumas ir viešoji tvarka, 5, 160-169.

Sommer, M., Njå, O., \& Lussand, K. (2017). Police officers' learning in relation to emergency management: A case study. Int. J. Disaster Risk Reduct, 21, 70-84.

Šalkauskaitė, A., Valickas, G., Grikšienė, R., \& Rukšènas, O. (2015). Policijos pareigūnų sprendimų prièmimas kritinėmis aplinkybėmis. Kriminologijos studijos, 3, $29-58$.

Thoits, P.A. (1999). Self, identity, stress, and mental health. In C.S. Aneshensel and J.C. Phelan (Eds.), Handbook of the Sociology of Mental Health (pp. 345-368). New York: Kluwer Academic/Plenum.

Uchroński, J. (2016). Role and tasks of the police in an airport crisis situation. Zeszyty Naukowe. Transport / Politechnika Ślaska, 93, 131-139.

Uspanova, Z.T., Turabayevaa, D.S., \& Ermolovichb, V.F. (2016). The Psychological Competence of Police Officers in Confidential Cooperation with Citizens. International Journal of Enviromental and Science Education, 11(10), 3497-3955.

Žukauskas, R., Burba, B., Rukšènas, O., Grigaliūnienè, V., \& Mitchell, J.T. (2009). A Study of Stress Affecting Police Officers in Lithuania. International Journal of Emergency Mental Health, 11(4), 205-214. 